\title{
Modern Thought of Photovoltaic Technology in the Implementation of Transit Oriented Development's Concept and Revitalization for Jakarta Old Town
}

\author{
Bahri Saeful ${ }^{1}$, Purwantiasning Ari Widyati ${ }^{2 *}$ \\ ${ }^{1}$ Faculty of Engineering, Department of Electrical Engineering, Universitas Muhammadiyah Jakarta, \\ Jalan Cempaka Putih Tengah 27, Jakarta 10510, Indonesia \\ ${ }^{2}$ Faculty of Engineering, Department of Architecture, Universitas Muhammadiyah Jakarta, Jalan \\ Cempaka Putih Tengah 27, Jakarta 10510, Indonesia
}

\begin{abstract}
The idea of this research is based on the development of the city which has a historical area, particularly Jakarta Old Town, which is become abandoned in some part area. The main problem of this research is how to implement of Transit Oriented Development's concept for historical buildings within the historical area and modern thought using photovoltaic technology. By doing a precedent study of some case studies, this research will give an alternative solution for local government to maintain historical area by combining between old and modern concept. As an outcome, this research will give a solution how to use the technology of photovoltaic in the implementation of Transit Oriented Development for historical area particularly Jakarta Old Town Area in Indonesia.
\end{abstract}

\section{Introduction}

The existence of many abandoned historical areas within the city center has encouraged an awareness of some parties particularly historians and conservators. Moreover, because there is a need to promote the identity of the city, local government has been encouraged as well to consider the issues of those abandoned historical areas. One of the significant issues of those abandoned historical areas is the lack of the maintenance as well as the lack of the utilities within the areas.

The problem of lack of the infrastructure within those abandoned historical areas will make the areas have a degradation of the quality. One of the concepts is by delivering the synergy concept within the areas to improve the quality of the built environment as well as the quality of the community who lives in the areas. Researchers have studied the conservation within the area of Jakarta Old Town with a different point of view. In this research, the researchers will try to propose the application of Transit Oriented Development within historical areas particularly the area of Jakarta Old Town. The problem

\footnotetext{
* Corresponding author: arwityas@yahoo.com
} 
within this area is the lack of comforts and safeness for pedestrian, especially all visitors within the area of Jakarta Old Town.

To support the implementation and the using of Transit Oriented Development, the researchers will propose the use of photovoltaic technology as a concept of using renewable energy. The using of this technology will cover in the use of electricity for the transportation within the area of Jakarta Old Town, which is in this case; the researchers will propose a tram as a public transport, and the use of lighting for night use.

By integrating these two fields study of electrical engineering (control system) and architecture (urban planning), the researchers will try to give a conceptual idea which could be used as a pilot project to implement a concept of Transit Oriented Development based on photovoltaic technology.

\section{Research method}

The researchers have conducted an area of Jakarta Old Town as a case study, which is very well known as a historical area in Jakarta. This area has been designated as a case study because this area has a significant historical value which could become the identity of the city and has a glorious in the past. The method of the research is qualitative research with a historical approach to describe the condition of the area either physical or non-physical aspects. At the end of the study, the researchers will provide design as a result.

\section{The concept of transit oriented development}

One of the issues within the area of Jakarta Old Town is the lack of comforts and safety for pedestrian especially the visitor of the area of Jakarta Old Town. The traffic in surrounding area of Jakarta Old Town has been regarded as a crowded one. Some areas within Jakarta have implemented the concept of Transit Oriented Development to tackle the problem of the traffic in Jakarta. To solve the problem within the area of Jakarta Old Town, the researchers have proposed a concept of Transit Oriented Development within the area. By implementing this concept, the area of Jakarta Old Town becomes integrated from one facility to another facility within the area. One of the main concepts of Transit Oriented Development is by providing the accessibility for pedestrian, transit for public transport to enhance the quality of the environment to be a comfort, safe, attractive and sustainable one.

Referring to the area of Jakarta Old Town, there are many visitors either domestic or international, and this condition has encouraged the area to be more attractive and has been improved physically and non physically. The researchers believe that this proposed solution by implementing the concept of Transit Oriented Development within the area of Jakarta Old Town will enhance the quality of the area and will encourage visitors to come. The concept of Transit Oriented Development will improve the character of the area as well because the concept will deliver facilities and accessibilities for pedestrian as well as the transit for public transport.

As Wijaya (2009) said that the concept of Transit Oriented Development had been started by promoting the concept of human mobility activity either with vehicles or by walking. Human mobility has been regarded as an activity which has been done a lot by the human and has been accommodated by the central activities which are integrated by transit points. These central activities have been connected one to another with comfort and safe radius as an effort to decrease the use of transportation [1].

It could be concluded that the concept of Transit Oriented Development is a concept to integrate all the accessibility using pedestrian way to minimize the mobility of public transport. This concept also designs the comfort and safe accessibility within the area which is walkable for visitors. Thus, to propose the concept, the researchers have analyzed the 
condition of the area of Jakarta Old Town, and will promote the alternative solution by providing the concept of Transit Oriented Development within the area by using a tram to minimize the distance of the area. This is because the condition of the area from one attraction to another is relatively far. Thus, this using of a tram will make the area more walkable to catch the attraction as near as possible for visitors.

\section{Photovoltaic technology}

Energy thermal that has been produced from the sun could be used to produce another energy to fulfill the human need such as energy thermal to make hot water as a heat source in heater machine cycle as moving energy. Another benefit of solar energy is to produce electricity through the using of a photovoltaic cell. The using of electrical energy from solar energy could become renewable energy for the future. Some researchers have done and stated that the using of solar energy becomes electrical energy has minimized the use of electrical energy. Referring to the previous research of Purwantiasning, et al. (2017), the using of electrical energy from solar energy by implementing the technology of control system for Fatahillah Museum, one of a historical building in Jakarta Old Town, could be maintained and minimized to $30 \%-60 \%$ [2].

According to that, the researchers will propose the using of technology photovoltaic within the area of Jakarta Old Town. The implementation of this technology will cover the using of the tram as public transport within the area, the using of lighting within the area at night time and the using of the lighting within some designated historical buildings within the area.

The word photovoltaic is referring to Greek; photos mean light and volta implies the name of a physician from Italy who found the electricity. In a simple way, photovoltaic could be defined as electricity from light. Photovoltaic could be defined as a process to convert light energy (sun) becomes electrical energy.

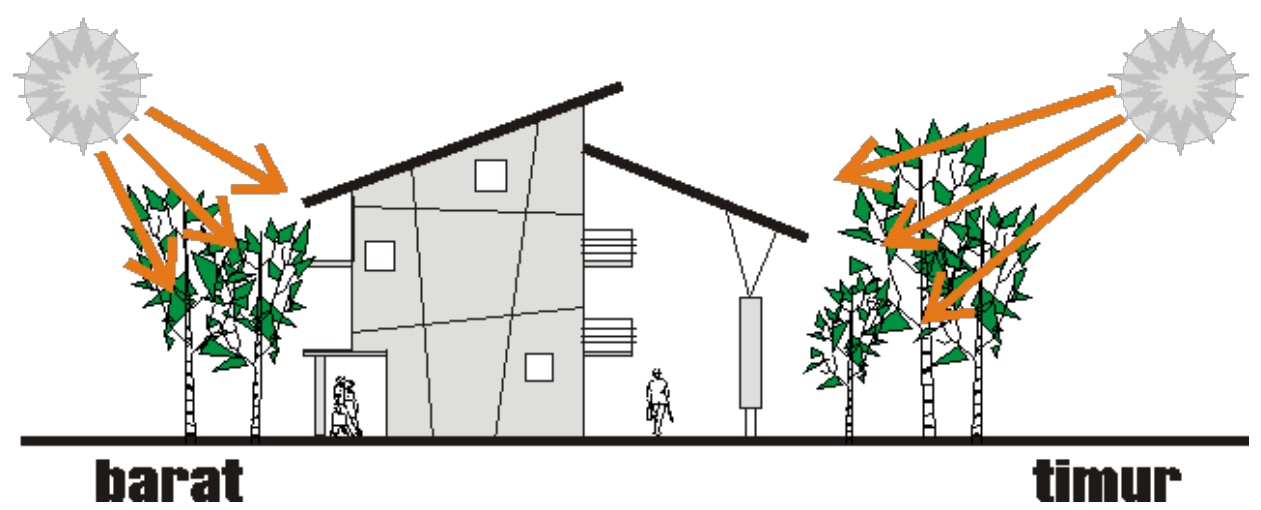

Fig. 1. Natural lighting from sun

Source : http://4.bp.blogspot.com, has been accessed on 31st December 2016

Quote from the book Basic Photovoltaic Principles and Methods (1982); it has been stated that the physical phenomenon responsible for converting light to electricity-the photovoltaic effect was first observed in 1839 by a French physicist, Edmund Becquerel. Becquerel noted a voltage appeared when one of two identical electrodes in a weak conducting solution was illuminated. The PV effect was first studied in solids, such as selenium, in the $1870 \mathrm{~s}$. In the 1880 s, selenium photovoltaic cells were built that exhibited 
$1 \%-2 \%$ efficiency in converting light to electricity. Selenium converts light in the visible part of the sun's spectrum; for this reason, it was quickly adopted by the then-emerging field of photography for photometric (light-measuring) devices. Even today, light-sensitive cells on cameras for adjusting shutter speed to match illumination are made of selenium [3].

It has been stated as well in the book, that today, photovoltaic systems are capable of transforming one kilowatt of solar energy falling on one square meter into about a hundred watts' of electricity. One-hundred watts can power most household appliances: a television, a stereo, an electric typewriter, or a lamp. In fact, standard solar cells covering the sunfacing roof space of a typical home can provide about 8500-kilowatt-hours of electricity annually, which is about the average household's yearly electric consumption. By comparison, a modern, 200-ton electric-arc steel furnace, demanding 50,000 kilowatts of electricity, would require about a square kilometre of land for a PV power supply [3].

\section{The area of Jakarta old town}

In this chapter, the researchers will discuss the area of Jakarta Old Town, from the physical condition to non-physical condition. The researchers will also discuss the regulation and the planning of the area of Jakarta Old Town as a designated area of conservation. By referring this regulation and the planning of Jakarta Old Town area, the researchers will analyze the possibility to propose the concept of Transit Oriented Development using technology photovoltaic. 


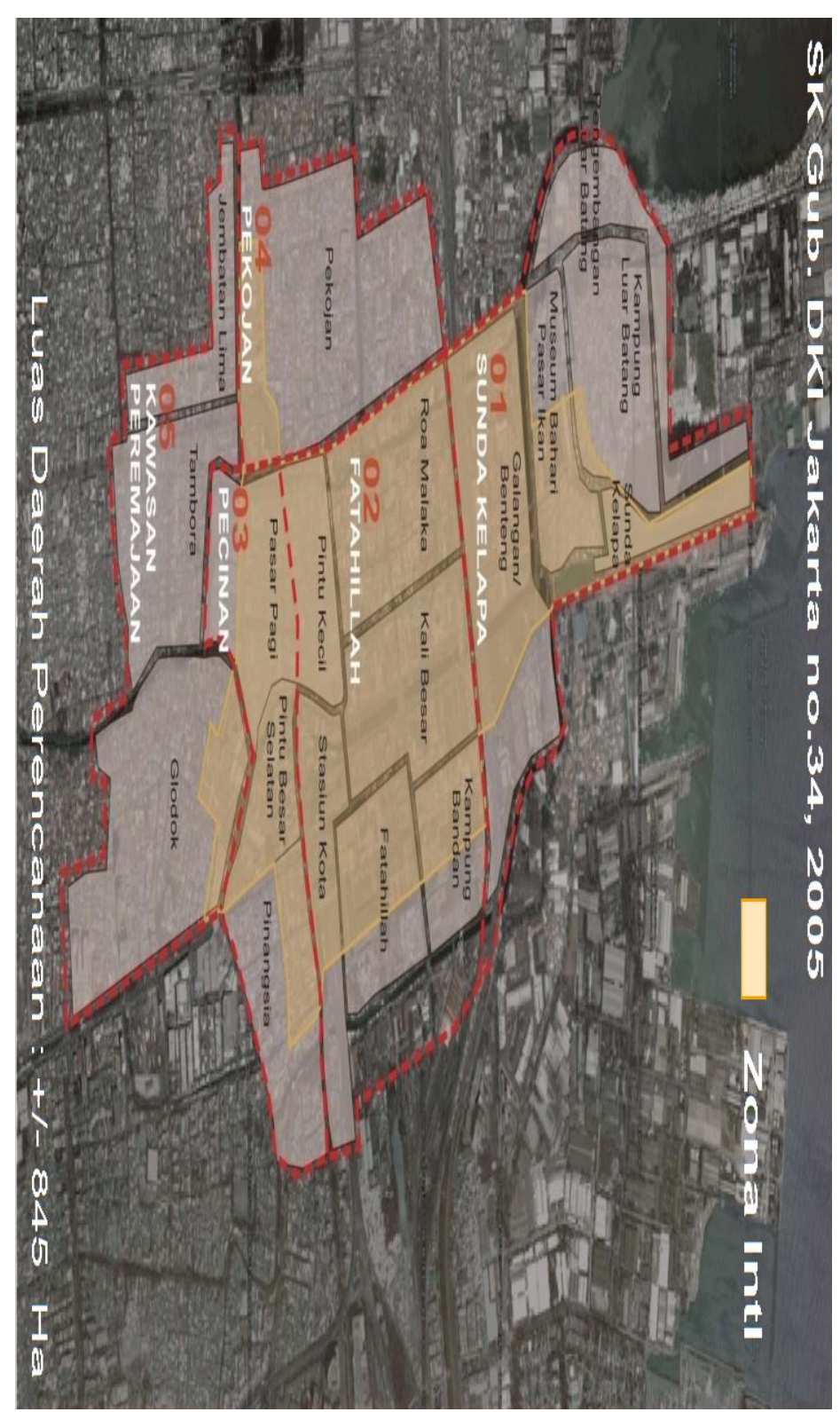

Fig. 2. The Zones of Jakarta Old Town's area from Zone 1-Sunda Kelapa, Zone 2-Fatahillah Square, Zone 3-Pecinan or China Town, Zone 4- Pekojan or Kampung Arab, Zone 5-Kawasan Peremajaan or Rejuvenation's Area. The core zone of the Jakarta Old Town is zone 2 which is covered the area of Fatahillah Square and the surrounding area.

Source : Rencana Induk Kota Tua Jakarta, 2008 [4]

Referring to Rencana Induk Kota Tua Jakarta (2008)- Master Plan of Jakarta Old Town, the area of Jakarta Old Town has some significant issues as well as significant potencies that could be promote to maintain the area to be a good built environment. There are some significant issues that has been defined as follows [4]:

1. Bad image of the area: an image that this area is full of pollution, traffic congested, crowded, unsafe and slum. 
2. The lack of vitality of the area : the variety of the activities within area is not compatible and it is not optimal in promoting the potency of historical old buildings within the area; there is un-integrated development within area

3. The lack of infrastructure within area which is not supported the development of the area : abandoned drainage, lack of pedestrian ways

4. The unorganized traffic within the area which affected the traffic jam, crowded, lack of accessibility to the area of attraction, un-integrated parking area

5. The significant degradation of the quality of built environment : air pollution, water pollution

6. The un-integrated policy: the separated regulation and policy between official division, unresponsive bureaucracy

7. Separated administrative border : the area still under two district : North Jakarta and West Jakarta

8. There is not institutional office available which has an entrepreneur skill and has an authority to plan, develop, market and control the strategy of the development of Jakarta Old Town.

On the other hand, there are also some significant potencies of the area of Jakarta Old Town as follow [4] :

1. The area of Jakarta Old Town was an international port area in the colonial era and it became the embryo of Jakarta and mixed community.

2. The heterogeneity of the society has been formed from the mixed culture from several ethnic (Chinese, Arabian, Dutch, England and Malay).

3. The structure of the city that has been formed at the riverside is similar with the cities in Dutch, with Ciliwung River as the center of economic activity.

4. The center marine tourism activity in the past played an important role in the aspect or area's development (government, social-politic, population, art and culture)

5. The support of infrastructure for road transportation as well as canal transportation will broaden the area of Jakarta Old Town to Glodok and Pasar Baru area.

6. There are so many architectural heritages from the colonial era, which have a European architecture style from 17 century. 


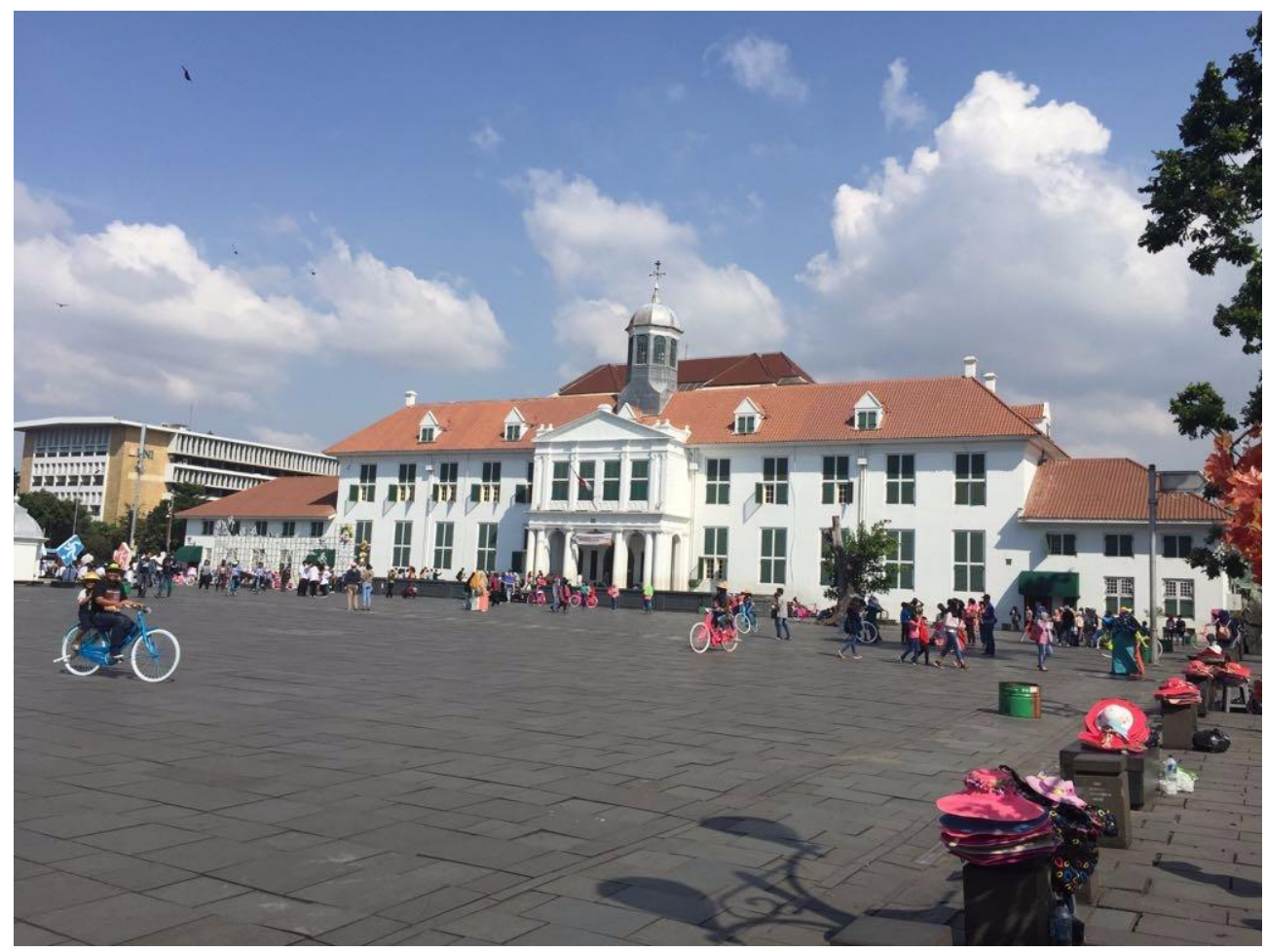

Fig. 3. One of the significant historical buildings within the area of Jakarta Old Town. The building very well known as Fatahillah Museum which is located in Fatahillah Square, the core zone of the area of Jakarta Old Town

Source : Private Documentation, 2018

According to the Master Plan of Jakarta Old Town [4], the development of the area of Jakarta Old Town will cover some points to solve the issues within the area. All the points will include:

1. To strengthen the existing activities within the area and to encourage the development of new business and economic activity;

2. To conserve and revitalize in the developing the area of Jakarta Old Town

3. To enhance the quality of infrastructure and public facilities within the area

4. To support the activity of social, art and culture within the area

5. To restore the main function of the area as a resident area with all supported activities

6. To develop the concept of public-private partnership through institutional system, law and urban management.

Referring to all the above significant issues, potencies and the strategy, the researchers could underlined that the development of the area of Jakarta Old Town should cover all aspect from economic, social and activities which is based on community's need. Through the observation and literature studies, the researcher stated that the core zone is the best choice to conduct the concept of Transit Oriented Development within the area of Jakarta Old Town. This is because, the area of core zone has been regarded as a special area with significant character and has more appreciation to the memory of past in the colonial era. This core zone also has a function as a central orientation and central of the living heritage 
within Jakarta Old Town. This area has a high limitation in the development activities, because there are many historical building with grade A.

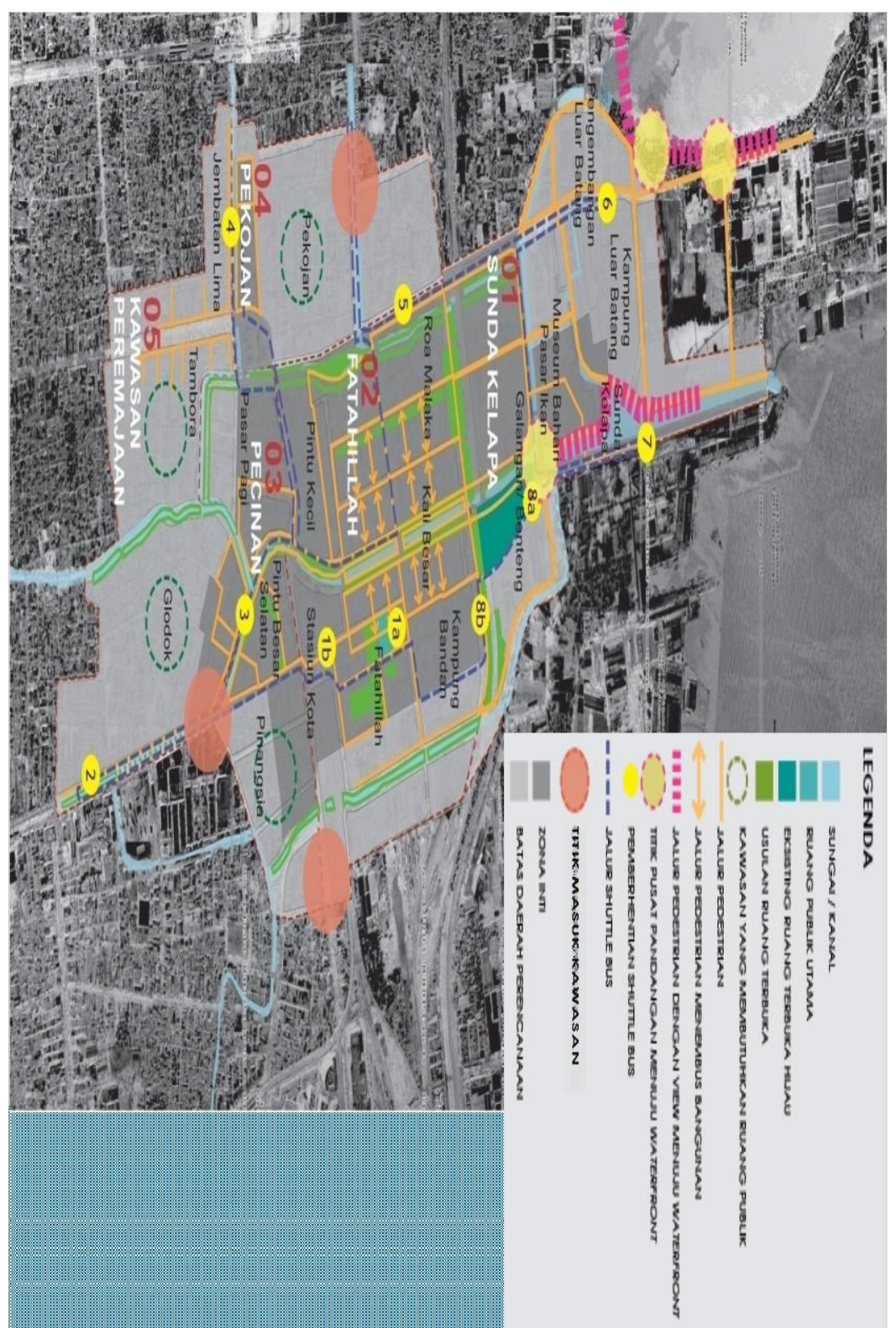

Fig. 4. The above map shows the streets, pedestrian ways also the open space and green area within the area of Jakarta Old Town

Source : Rencana Induk Kota Tua Jakarta, 2008 [4] 


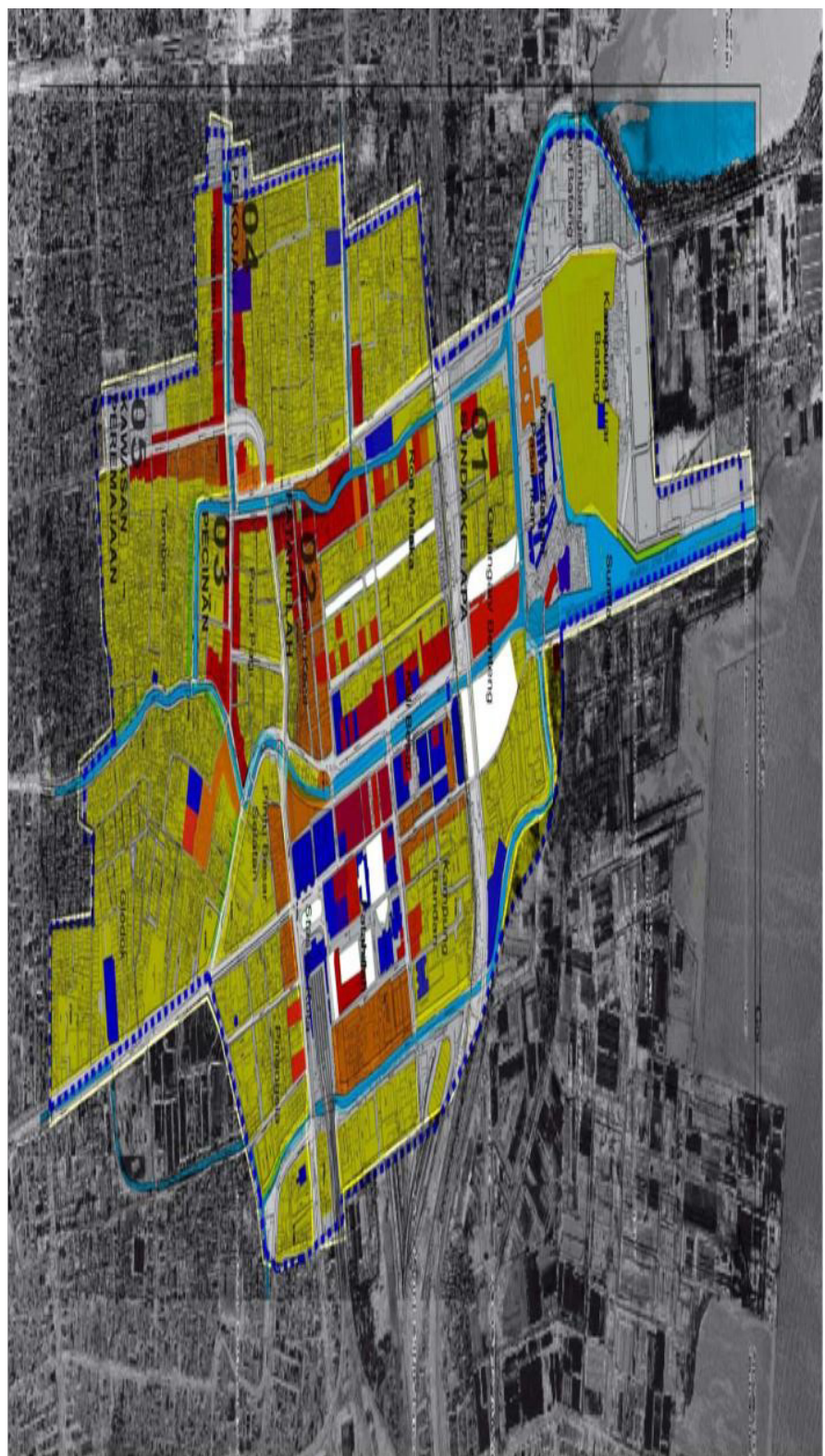

Fig. 5. The above map shows buildings within the area of Jakarta Old Town with Grade A (blue color), Grade B (red color), Grade C (orange color) and Grade D (yellow color)

Source : Rencana Induk Kota Tua Jakarta, 2008 [4]

The main principle of the development within the area of Jakarta Old Town is the circulation of pedestrian as well as the vehicles and also the linkage between one point to another. The development within the area should provide the circulation system that comfort, safe and continue and refer to the urban planning in macro scale. The development also should maintain the traffic management to minimize the traffic jam and crowd within the area to control the capacity and the mobilization of people and vehicles. The development also should cover the improvement of transportation system which covers the 
delivery and mobilization of visitors within the area without interfere the mobilization of pedestrian.

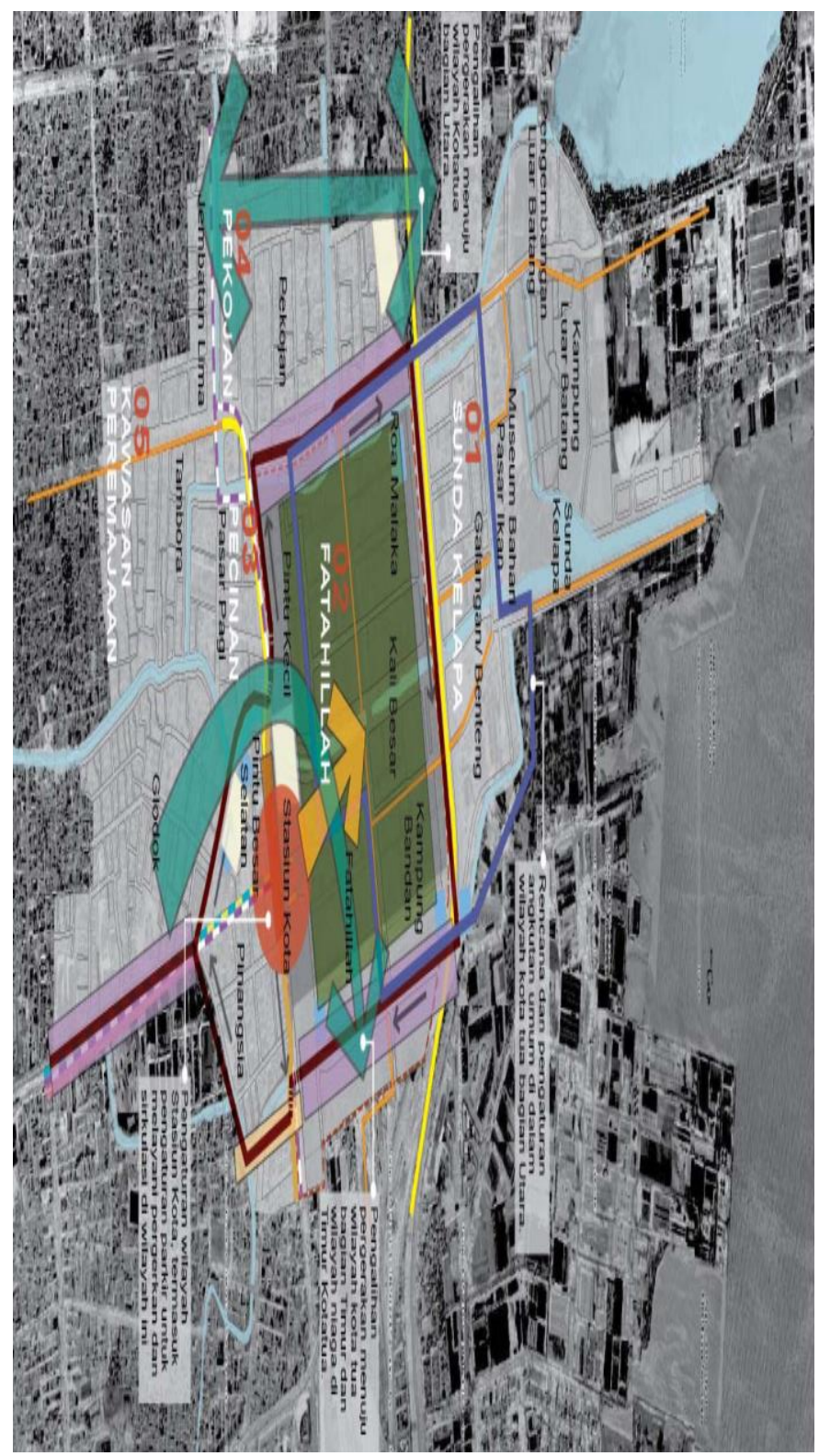

Fig. 6. The above map shows the circulation and the linkage within the area of Jakarta Old Town which is stated in the Master Plan of Jakarta Old Town

Source : Rencana Induk Kota Tua Jakarta, 2008 [4]

According to figure 6, the Master Plan of Jakarta Old Town has described the linkage and circulation within the area of Jakarta Old Town. The map shows the principle of the development of pedestrian way. The area Jakarta Old Town should be oriented to the comfort of pedestrian. Thus, there should be a development of pedestrian ways within the area. There should be a consideration that there is a limitation of range for walking. Either 
the area is walkable or not, the development should consider about it. The accessibility should be comfortable for pedestrian, and the distance of the attraction from one point to another should be considered as well.

Using the regulation and the Master Plan of Jakarta Old Town, the researchers try to propose a design by developing the circulation for visitors using a tram through tourism line between historical buildings within the area of Jakarta Old Town. This tram will be operated by using renewable energy well known as technology photovoltaic.

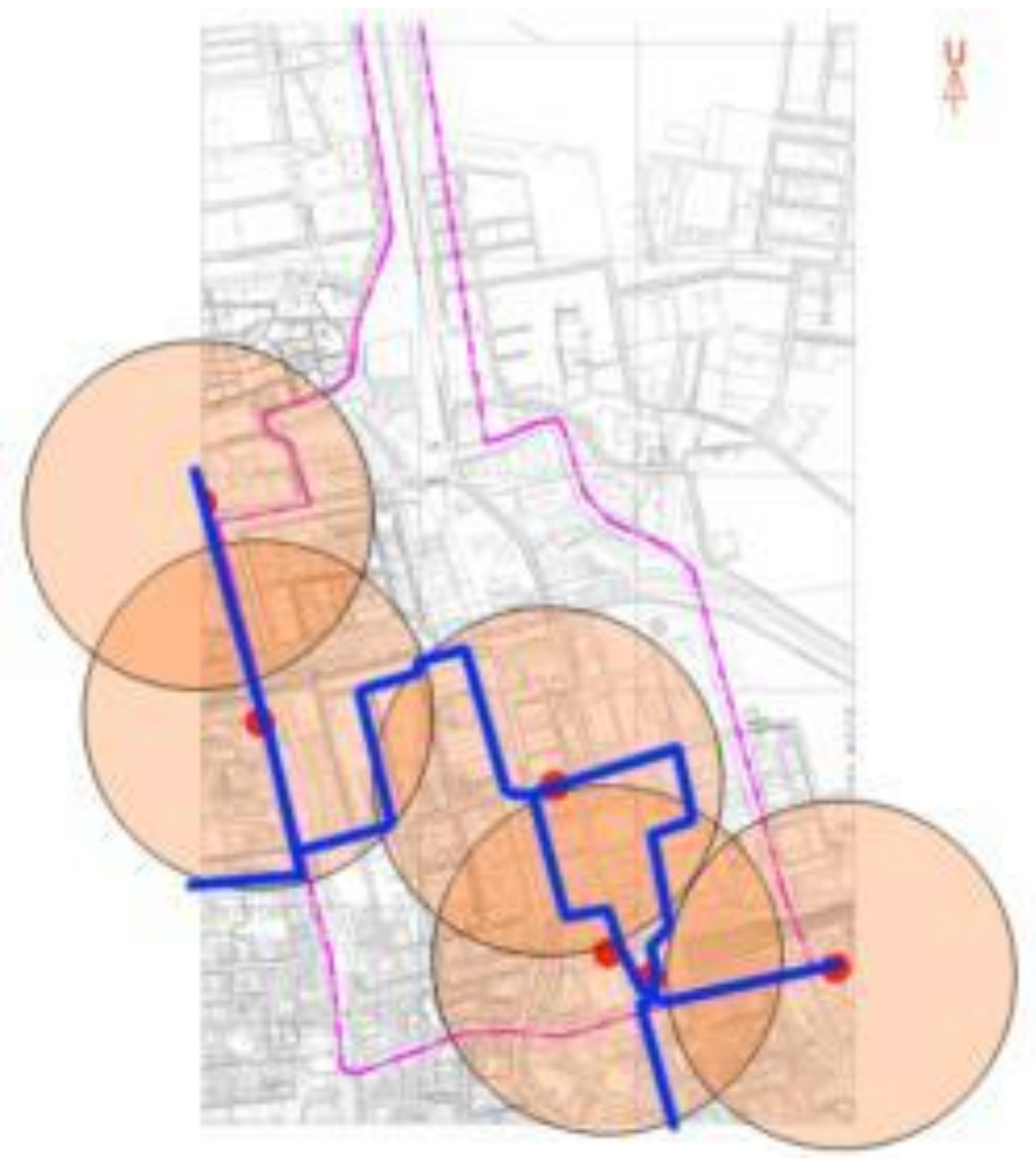

Fig. 7. The above map shows existing public transport, the point of transit and Trans Jakarta line Source : Analyze Result, 2017 


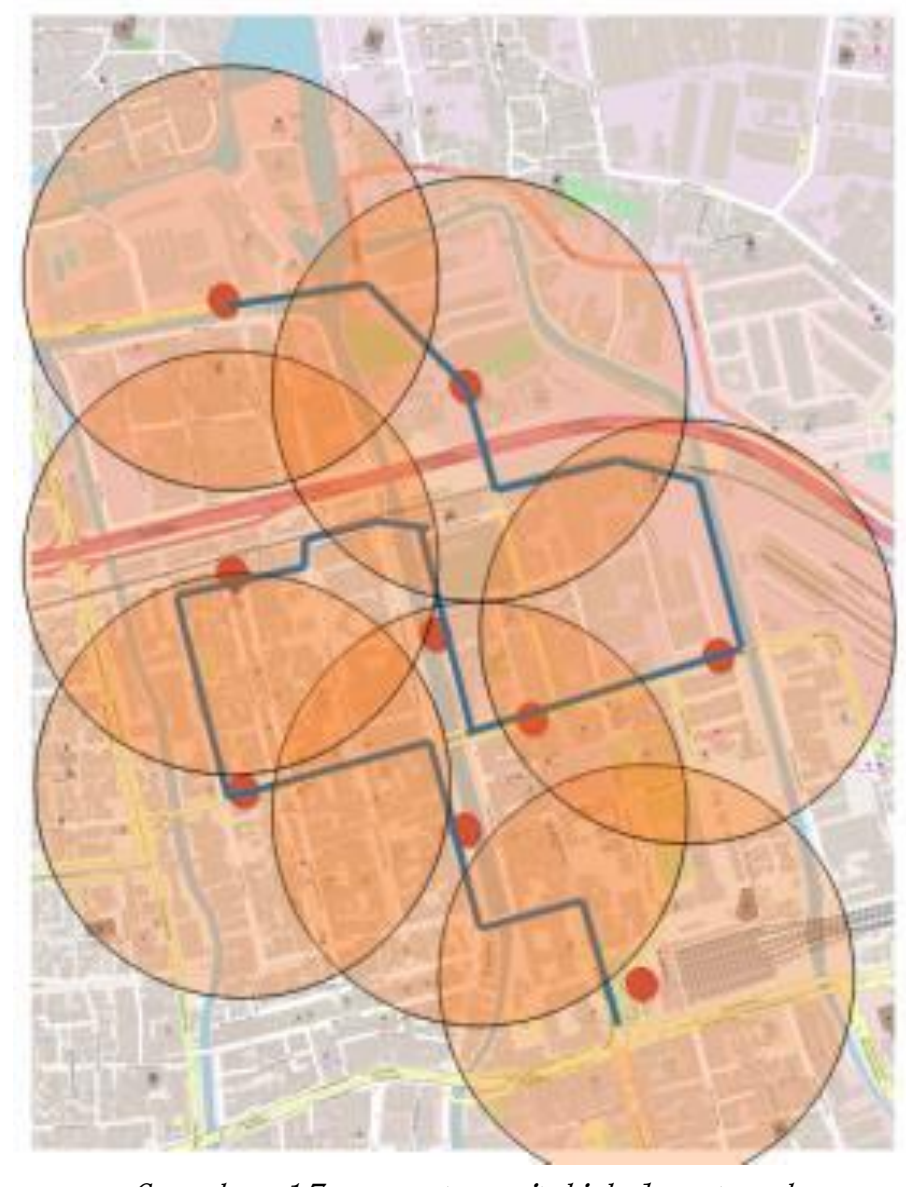

Fig. 8. The above map shows the development of transit point according to the analyze of figure 7 Source : Analyze Result, 2017

Through the above figure (figure 8), the researchers propose the line for the tram which will cover the area of Jakarta Old Town using the principle of maximum distance of walking (500 meters or 5 minutes' walk).

\section{Conclusion}

The concept of Transit Oriented Development could become the best solution to handle many issues in the Jakarta Old Town's area particularly the issue of comfort and safe for pedestrian as well as the issue of traffic and crowded. By distributing some transit point thoroughly within the area of Jakarta Old Town, pedestrian will access easily to all attraction point from one to another. This condition surely will enhance the quality of the build environment as well as to improve the number of visitors within the area. The comfort and safe place within the area will encourage visitors to come to Jakarta Old Town using public transportation; this will support to minimize the using of private vehicles. 


\section{References}

1. Wijaya, A. Penataan Ruang Yang Ramah Lingkungan Melalui Perencanaan TOD. Universitas Langlangbuana. Bandung. (2009).

2. Purwantiasning, AW; Bahri, S. An Application of Smart Building Concept for Historical Building Using Automatic Control System, Case Study: Fatahillah Museum. International Journal of Built Environment and Scientific Research. Universitas Muhammadiyah Jakarta. Volume 1 No. 2 Ed. December 2017. (2017).

3. The Midwest Research Institute. Basic Photovoltaci Principles and Methods. Solar Energy Research Institute. Colorado. United States of America. (1982).

4. Dinas Tata Ruang Pemerintah DKI Jakarta. Rencana Induk Kota Tua Jakarta-Master Plan of Jakarta Old Town. Pemerintah Kota DKI Jakarta. (2008). 